\title{
Community-based tourism initiatives and their contribution to sustainable local development
}

\author{
Marinês da Conceição Walkowski ${ }^{1 *}$, Paulo dos Santos Pires², Luciano Torres Tricárico ${ }^{3,}$ \\ University of Vale do Itajaí, Balneário Camboriú, SC, Brazil ${ }^{1 *}$, University of Vale do Itajaí, Balneário \\ Camboriúm, Brazil ${ }^{2,3}$ \\ marinesw@gmail.com ${ }^{*}$,pires@univali.br ${ }^{2}$,tricarico@univali.br ${ }^{3}$
}

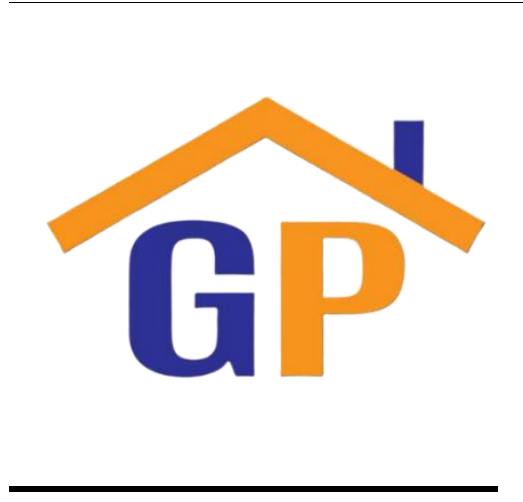

Article History

Received on 9 May 2020

$1^{\text {st }}$ Revision on 18 May 2020

$2^{\text {nd }}$ Revision on 24 May 2020

Accepted on 10 August 2020

\begin{abstract}
Purpose: The research question/purpose is to know which CBT initiatives are still active in Brazil, as well as the challenges that exist in the sustainable local development perspective.
\end{abstract}

Research Methodology: We based this exploratory research on extensive bibliographic research on the theme in addition to field observations. As a research strategy, we used the multiple case study involving two Brazilian initiatives: the Rede Tucum, in Ceará, and the Acolhida na Colônia, in Santa Catarina.

Results: The main results showed that despite the difficulties associated with the CBT development, both projects have remained due to the strong articulation between the leaders, partnerships with educational institutions and entities, the methodology maintenance provided by the project's technical team, and the diversification of tourism offer based on sustainability actions.

Limitations: The limitation was access to fishing communities.

Contribution: The contribution will assist in advancing studies with this theme and in tourism disciplines of local base.

Keywords: Community-based tourism, Sustainable local development, Rede Tucum, Acolhida na Colônia

How to cite: Walkowski, M. d. C., Pires, P. d. S., Tricárico, L. T. (2019). Community-based tourism initiatives and their contribution to sustainable local development. Journal of Sustainable Tourism and Entrepreneurship, 1(1), 55-67.

\section{Introduction}

The primary motivation of traveling to natural destinations is the need to disrupt the routine, the search for conviviality with nature, and the residents. The landscape and the existing relationships make this change possible and offer the tourist an experience exchange. The Brazilian rural space has been going through some modifications, especially regarding the relationships and means of work. These modifications enable farmers to increase family income through new activities such as tourism, which provides an improvement in the quality of life and the permanence of men in the countryside. The boundaries reduction between rural and urban spaces is due to the rural spaces are pursuing activities previously common to urban areas, seeking to streamline rural activities (Miranda, 2012; Machado \& Tomazzoni, 2011; Santos, 2004).

In the last years, a few tourism initiatives occurred in both spaces (rural and urban), and it has assisted in job creation and income for local communities. Community-based tourism (CBT) arose from the need to value local culture, diversify the offer of differentiated services, and a history of resistance to mass tourism (Manzanares \& Mateos, 2017; Coriolano, 2009; Sampaio \& Zamignan, 2012; Deere \& Royce, 2019). From experiences in other countries, there has been an increase in world awareness, seeking more and more tourism initiatives that are concerned with environmental conservation through innovative solutions aiming at sustainability in several dimensions, such as social, cultural, economic, environmental, and political (Palacios, 2016; Silva, Borborema \& Christoffoli, 2016). 
In Brazil, the Ceará and Santa Catarina state, due to their vocation to tourism, they are investing in new activities that are increasingly growing through CBT initiatives, in partnership with several Nongovernmental organizations (NGO) and entities focused on the tourism industry. This fact has aroused the interest of cities to reduce social inequalities and environmental impacts caused by the consequences of mass tourism, seeking new alternatives for boosting tourism activities in coastal and rural spaces.

In order to deepen and update the knowledge on this matter, an investigation about the CBT initiatives in Brazil is required to confirm their stay, the social actors, the support networks, the central worked division, and the relevance of these initiatives as a paradigm for sustainable local development. At the theoretical level, this paper also aims to systematize methodological and theoretical knowledge about CBT and its influence on sustainable local development.

\section{Literature review and hypothesis development}

\subsection{Community-Based Tourism}

The Community-Based Tourism (CBT) concept is born considering the perspective of thinking in better use of productive issues. Therefore, the CBT was created in response to the aspirations of several indigenous people and traditional communities' organizations, whose purpose is to promote technical assistance and institutional backing to facilitate small rural business access to business development services and new markets. In Latin America, the CBT phenomenon has as its premise the endogenous basis in tourism planning and development, and one of the ways for its organizations is the Latin American Community Tourism Network (REDTURS), established in 2001 in order to articulate initiatives that have been built at different local and national scales influencing the development of several practices in the territory. The development of CBT networks in Latin America is still a new phenomenon, but it involves most of the countries; Ecuador and Argentina are the countries with the highest number of networks articulated at both national and local levels.

CBT concerns an endogenous or local development understood as the process of economic growth and structural change, guided by the community and its active participation considering the satisfaction of their own needs (Okazaki, 2008; Tolkach, King \& Pearlman, 2013; Lee, 2019; Mayaka, Croy \& Cox, 2017; Teixeira, Vieira \& Mayr, 2019; Holladay \& Powell, 2013). At the end of the 20th century and beginning of the 21 st century, it is notable that the development of a few tourism activities is occurring through endogenous local initiatives based on community initiatives. In Brazil, this fact is verified by the guidelines of the National Tourism Regionalization Program, which focuses on encouraging cooperation between local actors and public/private management institutions, in order to promote more sustainable tourism (Bursztyn et al., 2009; Maldonado, 2009).

Coriolano (2009, p. 70) presents the community tourism as "one in which communities associatively organize local productive arrangements, having effective control of land and economic activities associated with the tourism exploitation". The association between the involved ones can be formal or informal once these initiatives are quite incipient, usually start in territories lacking minimal infrastructure, and reflect an endogenous process. This way, "the associations play the role of being a new tourist entity, an intermediary agent between the state's articulations in tourism policies and the competitive will of the private entrepreneur" (Brambatti \& Nitsche, 2018, p. 18).

According to Bursztyn et al. (2009), CBT is where the local society has sufficient control over its development and management. It occurs through the involvement in the whole process - since the beginning - by everyone, where the actions towards tourism should provide most of the benefits to the local population. The CBT differential lies in the cultural and human dimension, aimed at fostering quality intercultural meetings with visitors. It is a type of organization based on community heritage resources self-management, concerned with democratic and sympathetic practices at work and with the distribution of generated benefits (Maldonado, 2006; Palacios, 2016).

It is noteworthy to highlight that the discussion about CBT in Brazil began in 1997 with the National Meeting of Local Base Tourism (ENTBL), it is the first academic event to address and reflect on the tourism phenomenon and its impacts on small communities. From then on, several initiatives took 
place between 1998 and 2000, consolidating in 2003, with the first Community-based Tourism Seminar, gathering several CBT initiatives in Brazil (Irving, 2009). CBT's most significant potential lies in community participation in doing tourism as an integral part of sustainable tourism development, where the community expresses its wishes and social aspirations, and CBT opens this space for the community, even with its individuality, to engage in a collective construction in search of a better quality of life (Gómez et al., 2015; Moraes et al., 2017; Sampaio \& Zamignan, 2012).

The so-called community-based tourism emerges as opposed to conventional or mass tourism. As stated by Bursztyn et al. (2009), Pires (2002), Ruschmann (1999), and Mano et al. (2017), an example of mass tourism is the large resorts that end up causing real estate speculation and the mischaracterization of local culture. This outcome has caused some communities to fight for their rights, creating an alternative kind of tourism. Many of these communities concentrated in the countryside or spaces in which traditional communities such as fishermen, quilombola groups, indigenous people, and other minority groups, like the extractivist, live.

\subsection{CBT initiatives on land}

In recent years, there have been discussions regarding changes in the ways of working in the Brazilian rural space. These modifications enable farmers to increase family income through new nonagricultural activities such as tourism. The boundaries reduction between the rural and urban spaces is due to the rural being adhering to activities previously common to urban environments. However, there are still some inequalities regarding the lack of primary conditions and infrastructure. The territory notion becomes broader as it embraces several other dimensions, including the elements that compose the landscape and planning as a tool for arranging these relations. However, the territorial logic is to build and strengthen interdependencies between economic, political, social, and spatial spheres (Cazzella, 2007; Rodrigues, 2006).

In this sense, territorial development occurs when there is integration by representatives of the public governance and society, by the diversity of institutional arrangements and by the elements that make up the natural and cultural landscape. Moreover, the territorial development may influence the development of public policies, gaining new meanings, aiming at sustainable development (Miranda, 2012; Machado \& Tomazzoni, 2011). In Brazil, some states have invested in new activities in the countryside and coastal spaces that have been growing increasingly through initiatives of several NGOs and entities focused on the tourism industry. This fact has aroused the interest of counties to reduce social inequalities and seek new alternatives for boosting agricultural and non-agricultural activities, for example.

These activities emerged because of the need to streamline rural activities, the process of real estate speculation, and mass tourism in coastal areas to rescue the esteem of communities and the territory's defense (Vera, 2016). The CBT, while "new conception of tourism is also influenced by changes in the visitors' new attitudes, which seeks for tourist experiences with natural and cultural values, which strive for the authenticity and originality of the places, and for the responsibility and concern with biodiversity, through interaction with the visited community" (Moraes et al., 2017, p. 14).

The local development is currently based on several models and factors that generate different practices and dynamics. Some factors, such as culture, tradition, belief, organizational arrangements, freedom, social capital, and associations, when integrated, tend to enhance local endogenous assets. The local development process involves, besides the social transformation, the use of local differences; so, the site must take advantage of their comparative advantages and diversify their economy based on the resources of each site (Damo, 2006).

Due to its complex character, social media can develop unique spaces creating an offer of attractive services and products. The impact of these media is transformative and beneficial to associations and small businesses and can result in social marketing tools and experiences (Sharpley, 2014; Henche \& Carrera, 2017). From this perspective, tourism can lead to the development of a social transformation process that supposes an accumulation and interaction of human, institutional, and physical capital. Thus, initiatives such as sympathetic tourism, fair tourism, ecotourism, among others, have emerged. 
These initiatives constitute responsible tourism that reinforces the local identity and cultures, strengthens community participation and encourages knowledge and mutual learning between tourists and residents, generating a thoughtful exchange between the parties (Moraleda et al., 2016; Onyx et al., 2017; Brusadin \& Netto, 2016).

The landmark of the new rurality comes with new types of tourism integrated with the rural tourism, agritourism, ecotourism, ethnic tourism, among others, and it has been possible because of public policies directed to boosting rural territories. Also, there are actions from government agencies, universities, and communities (Vera, 2016). Thus, Grimm \& Sampaio (2011) define CBT as a category composed of social enterprises that offer their visitors activities that, by their sharing quality, are called experiences. According to the authors, these experiences occur mostly during visits to protected areas, where there is also a greater "intimacy of hosts with nature, in a homestay where relationships become closer, more intimate and authentic, as well as participating in local folk festivals where one experiences local culture" (Grimm \& Sampaio, 2011, p. 8).

Finally, Guzzatti (2018) considers that CBT is necessarily designed together with the community, never designed "for" the community and hardly only "by" the community. These initiatives mobilize part of the local population, value the agricultural and handcrafted productions, generating income able to contribute to the financing of new projects (education, culture, health, environment, and production). CBT is also (above all) an element of social dynamics, openness, respect, and cultural exchanges. Through this culture meeting, CBT puts into perspective the evolution of societies, also creating the conditions for new solidarities between people of different cultures.

\section{Research methodology}

This paper is exploratory and descriptive research with a qualitative approach and uses primary and secondary data. The primary data is the CBT initiatives: the Rede Tucum in Icapuí, Beberibe, Ponta Grossa, and Prainha do Canto Verde, all these cities are on the coast of Ceará State; and the Acolhida na Colônia in Santa Catarina State.

\subsection{Data collection and procedure}

We used journal articles on CBT initiatives and its influence on sustainable local development as secondary data. We performed a search on SciELO, EBSCOhost, Elsevier, and Brazil CAPES Journal Portal platforms on this issue, considering the time cut from 1998 to 2019. Besides the field observations and data collection. The structured interview script was adapted from Gómez et al. (2015), which addresses community participation in CBT and is structured into four categories, with 13 statements. Category 1 has statements related to the establishment of tourism and the natural and cultural resources of the place of interest. In category 2, the questions seek to identify the acting subjects and their role in tourism development in the community. Category 3 has questions focused on destination management, the developed activities, the tourism segments (ecotourism, agritourism, rural tourism) included in the process, and the services and products that are offered. Category 4 is about the outcomes, difficulties, and challenges.

The research was conducted in the counties of Icapuí, Beberibe, Ponta Grossa, and Prainha do Canto Verde, in Ceará State (Brazil). We interviewed the Rede Tucum managers and the technical team of Icapuí. Also, we used field observations of Acolhida na Colônia, promoting a comparison between both CBT initiatives. The data utilized for this study were collected in September 2018 through in loco spatial reading, by photographic images, recordings, and surveys in Ceará's communities.

\subsection{Community-based tourism projects}

The CBT (as well as ecotourism, agritourism) has reported local culture, tangible, and intangible heritage conservation as motivation for residents and visitors. Among the examples, the case of the Coqueirinho Settlement in Fortim and the communities belonging to the Rede Tucum, both in Ceará State; the Acolhida na Colônia in Santa Catarina, and the Caminhos Rurais in the Rio Grande do Sul State (Coriolano \& Vasconcelos, 2012). 
The Rede Tucum is an articulation of groups organized in thirteen communities of the coast of Ceará that develop community tourism initiatives, made up of indigenous populations' representatives, fishers, and farmers, offering tourist services of lodging, food, nature trails, and sea rides. The goal is to promote interaction between society and nature, valuing cultures and territories, economically integrating tourism with traditional activities in order to produce benefits for the whole community. Established in 2001, the Tucum currently gathers thirteen coastal communities in different cities. They are, Tatajuba (Camocim), Curral Velho (Acaraú), Caetanos de Cima (Amontada), Flecheiras (Trairí), Etnia Tapeba (Caucaia), Etnia Indígena Jenipapo-Kanindé (Aquiraz), Batoque (Aquiraz), Prainha do Canto Verde (Beberibe), Assentamento Coqueirinho (Fortim), Ponta Grossa (Icapuí), Tremembé (Icapuí), Centro de Formação Frei Humberto (MST-Fortaleza), Associação Mulheres em Movimento (Conjunto Palmeiras, Fortaleza) (Coelho, Caetano \& Santos ,2016).

Among the CBT initiatives that stood out for the promotion of rural space in Santa Catarina, is the agritourism proposal of Acolhida na Colônia Association, as an outcome of a movement organized by the Ecological Farmers of the Serra Geral Hills Association (AGRECO) in 1996. AGRECO came up with the family farmers' desire to remain on their land, supported by a group of technicians committed to sustainable development, respecting the environment. The farmers' organization and the initiative to produce organic food associated to tourism gave rise to the Associação de Agroturismo Acolhida na Colônia (AAAC) (Acolhida na Colônia Agritourism Association) and its affiliation with the Accueil Paysan Network (operating in France since 1987), which has the proposal to value the way of life in the countryside through ecological agritourism (Guzzatti, 2010).

Founded in 1998, the AAAC has earned the respect of national and international institutions until now. In 2008, AAAC earned the title of "Destination Reference" in the rural tourism segment. In Brazil, according to the Regionalization Macro program of the National Tourism Plan 2007/2010, from an arrangement consisting of the four counties: Santa Rosa de Lima, Anitápolis, Rancho Queimado, and Urubici. Such recognition has brought great benefits, especially in the destination propaganda. The project is based on six counties, participating in the territories of the Regional Development Secretariats, established by the Santa Catarina government, and one county in Rio de Janeiro State (AAAC, 2020).

The Encosta da Serra Geral (Serra Geral Hills) territory has the most significant number of cities involved with the project: Rancho Queimado, Anitápolis, Santa Rosa de Lima, Grão Pará, and Gravatal. The Acolhida da Colônia also expanded through a project to the following cities in Santa Catarina: Aurora, Atalanta, Agronômica, Agrolândia, Vitor Meirelle, Witmarsum, Presidente Getúlio, Lontras, and Presidente Nereu, based on resources from the Ministry of Agrarian Development (AAAC, 2020). Moreover, based on bidding contracts with the municipal government, it is being expanded to Paulo Lopes, São Bonifácio, and Quiriri Intermunicipal Consortium (composed by Campo Alegre, Corupá, Rio Negrinho, and São Bento do Sul).

\section{Results and discussions}

\subsection{The general context of CBT in Ceará and Santa Catarina}

In Ceará State, we visited the following communities: Icapuí, Beberibe, Ponta Grossa, and Prainha do Canto Verde. Regarding the residents' lifestyle, most of them are natives and carry out activities such as fishing and agriculture. The subjects involved in the development process of CBT are also natives and residents of the community that identifies themselves with the initiatives. Residents participate in activities such as local guiding, cooking classes, lodging, among others.

In Icapuí, fishing is the main activity, followed by salt production and shrimp farms (see figures 5 and 6). The community recognizes the need to rescue the local culture through activities such as puppet theater, lace, maze, crochet, shell crafts, as well as the local festivities such as the patron festival (St. Peter) and the Papangus festival (Holy Week). There is also a handicraft market in downtown Icapuí where they sell local produce. The culinary highlights are tapioca, seafood dishes, and typical fruits. The community stands out for its direct relationship with sustainable practices since there are projects for the preservation of algae species, and the CBT initiative in Icapuí itself is entitled "Sustainable 
Community Tourism". There is a project called Olho na Água and an environmental station called Mangue Pequeno, where lectures and environmental education activities are offered to the community and visitors (see figures 1, 2, 3, and 4).
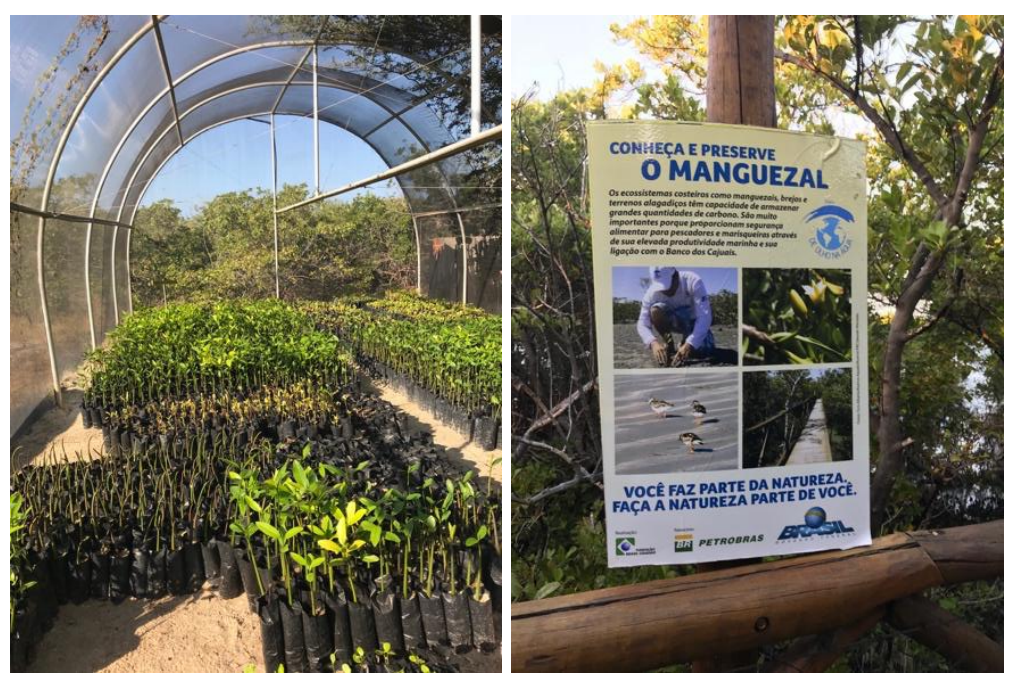

Figures 1 and 2: Algae nursery and Olho na Água project
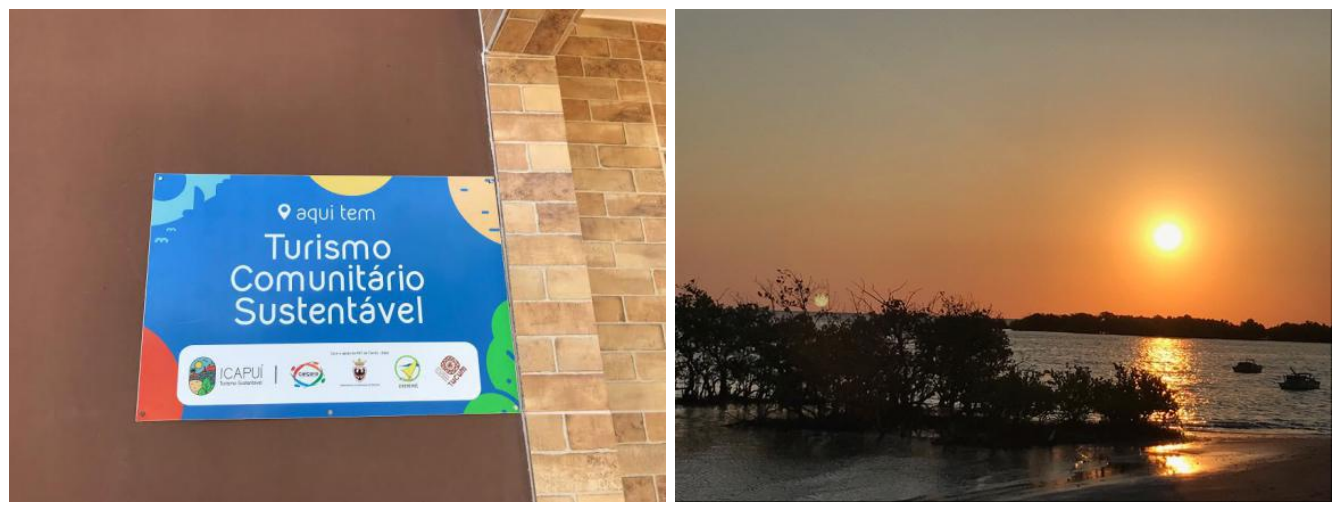

Figures 3 and 4: Signs and Icapuí community

The beginning of the CBT project was in partnership with the Italian Tremembé Association and the Caiçara Institute. Initially, eight families with interest and who had the potential for tourism were outlined. From then on, the participatory diagnosis was initiated in the properties that already developed tourism activities. These families were benefited from the Tremembé Association in partnership with the Caiçara Institute; this last one is responsible for resource management and hiring technicians. The families also received training from SENAC, SEBRAE, and the Federal University of Ceará. The managers are responsible for articulation, technical assistance, and accountability.

Regarding the activities' management, the agreements happen informally, through a conduct code among the associates. Recently, a Standard Book was implemented based on the model of the Acolhida na Colônia. The actions are coordinated by a group of six managers, representatives of each area - lodging, trails, walks, culinary, residents' association, and youth groups. The values of the services offered are defined together with the associated ones. The main activities offered in the communities are lodging, nature trails, walks, food, and cultural night. There were ecotourism activities and sale of colonial products in urban and rural places, in addition to the crafts made by carnauba straw, developed by one of the oldest residents of the Icapuí community. 

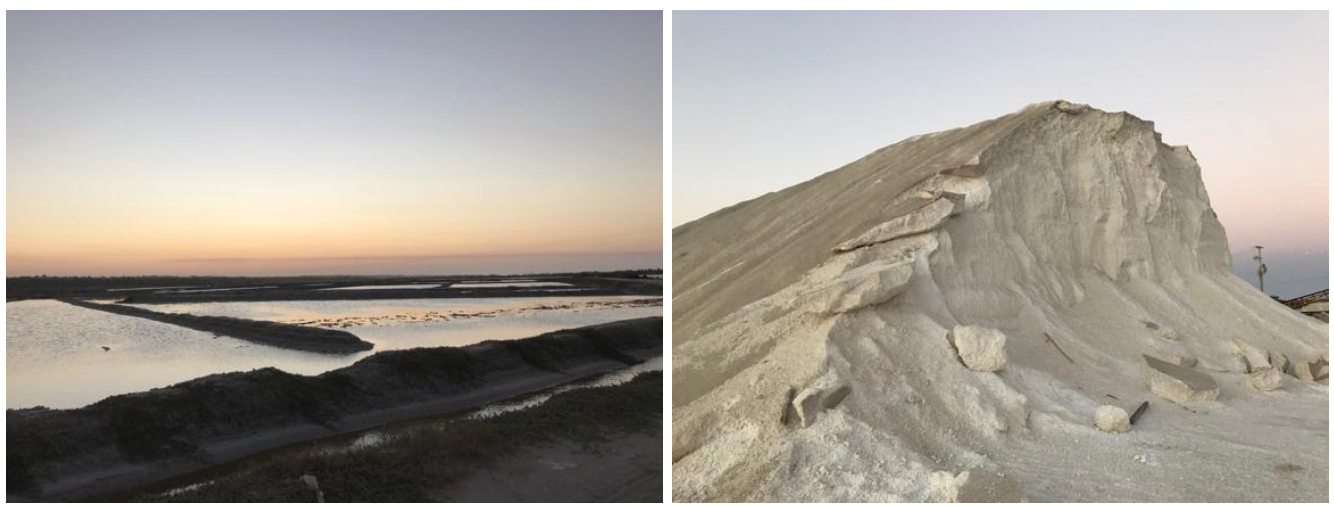

Figures 5 and 6: Shrimp farms and salt pans in Icapuí

During the interview with the coordinators (Praia do Canto Verde and Icapuí), they highlighted that the creation of Rede Tucum and the recognition are the main results. Regarding the difficulties and challenges, there is the (de)valuation of the Rede Tucum by the State, maintenance of projects and resources, centralized communication, meeting the expectations of the community regarding the financial return, the lack of specific public policies for this type of initiative, and the pressure from the conventional tourism industry.

In Ponta Grossa (figures 7 and 8), one of the oldest associated argued that the tourism in the area is incipient compared to other destinations but stands out for the history of resistance and struggle for permanence in the territory. The area stands out as a fishermen community where there was no access and not even electricity. Initially, tourism emerged from the sale of seafood and lobster dishes, and gradually, lodgings at the fishermen's house. The community currently has 50 beds for tourism, generating income for everyone in the community.

Also, according to reports, in recent years, many people interested in buying lots have appeared, and the families have chosen not to sell the lots and to preserve nature. In this sense, the notion of environmental education and awareness in the community is a continuous process. About the job creation in the community, there are positions for maid, waiter, cook, guides, and drivers. They also offer activities such as buggy ride, scuba diving, lobster snacks, among others.
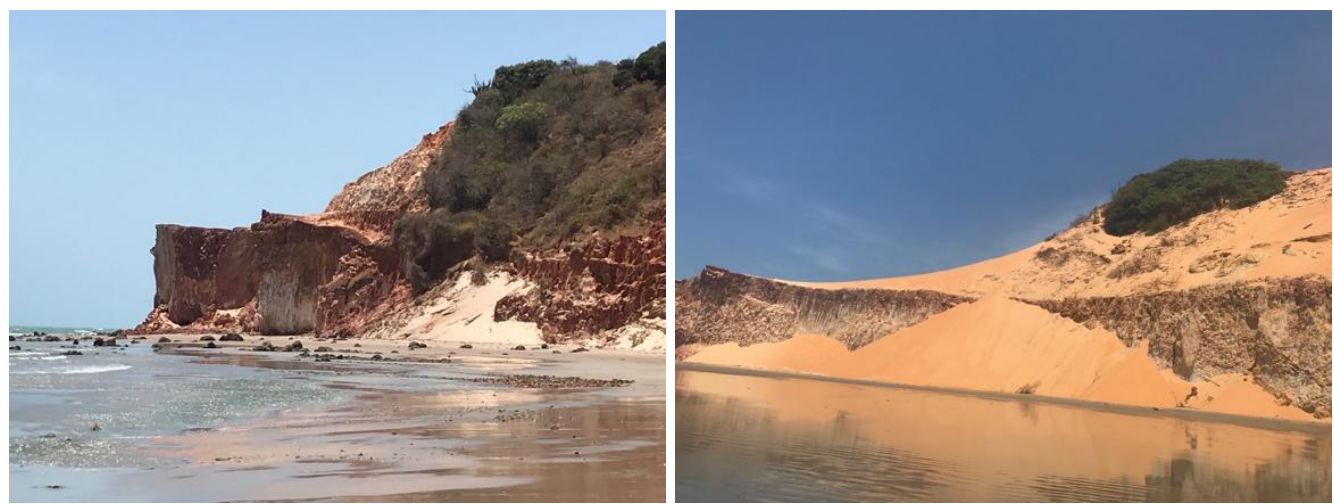

Figures 7 and 8: Ponta Grossa landscape

In the Beberibe community, a resident pointed out that the main activity developed is traditional cuisine. The area suffers from prolonged droughts, and it has a community mandala consortium (performed by several residents), developed by the Olho na Água project and the environmental station; there is also a native bee production (figures 9 and 10). Among the traditional dishes, the 
Mariscada no Coco Verde is the most famous, besides the colonial products. The community receives qualified training from Senar .
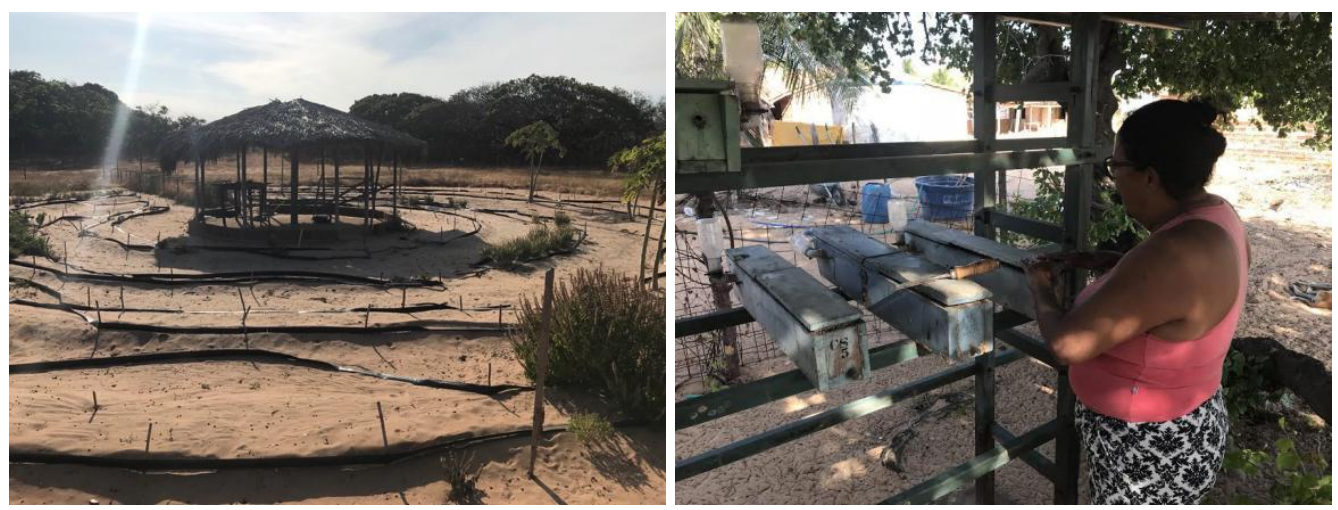

Figures 9 and 10: Community mandala and beehive

The Rede Tucum headquarter (figures 11 and 12) was built with support from the Italian Tremembé Association, which supports CBT projects in Brazil. The partnership began in 2000, together with the Terramar Institute, Caiçara Institute, and Prainha do Canto Verde Friends Association (currently extinct).
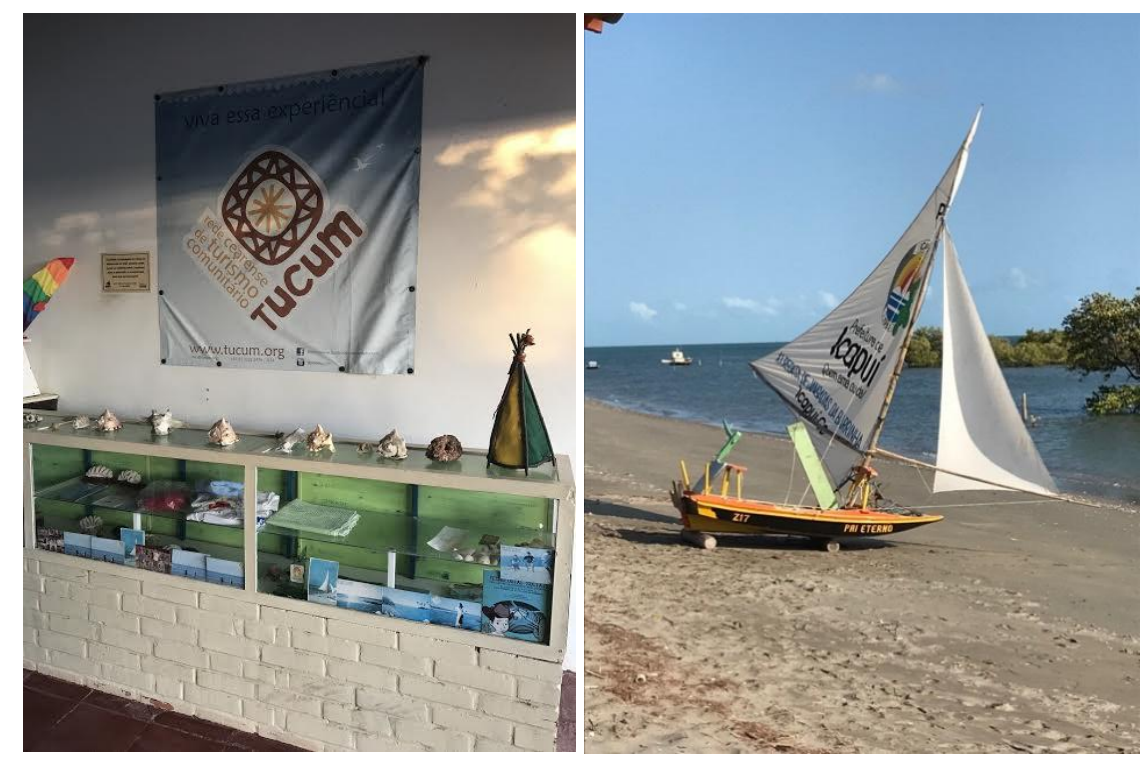

Figures 11 and 12: Rede Tucum headquarter

Since then, Tucum has been strengthening in the territory, and the main challenges faced is the lack of infrastructure and communication between the network. The communication strategies of the products and services offered, access conditions, payment methods, among others, are fundamental to the success of the visitor's experience and enable them to enjoy their moments outside the daily routine. Also noteworthy is the lack of public policies, whether federal, state, or municipal, to support the implementation of CBT projects in Brazil (Guzzatti, 2018).

In the Acolhida na Colônia Association, in Santa Catarina, about the community tourism facilities, which may be public or private, the idea is to "adapt" existing idle structures, such as a bedroom, a car garage, or a shed. Two factors stand out, the guarantee of a minimum quality and comfort to the visitor that allows a pleasant stay and, mainly, safety; and the gradual implementation of the business 
that allows, on the one hand, the investor not to be indebted and, also, that those involved can go on experiencing the new activity and decide to its maintenance, continuity, and expansion.

At this point, the practice allows a better understanding of the demands and visitor's needs and allows those involved to comprehend how the activity can be harmonized with their lives' dynamics. An exciting strategy used in some CBT projects is the formulation, by several involved actors, of a standard book, a guideline, and the implementation of a certification program (the Acolhida na Colônia and Rede Tucum, for example) (Guzzatti, 2018).

Regarding the methodology, the standard book works as a guiding instrument that the establishments should follow, using the rules and agreements made by those involved in the CBT project, without losing the specifics in the way of doing of each associate. The diversity of agricultural production, organic cultivation, training of local producers for the use of permaculture techniques has been the focus of the Acolhida na Colônia project. In each of these properties, different types of service are developed, focusing on the reciprocity between them. It can be food, lodging, products sale, and leisure activities.

\subsection{Rede Tucum: community ecotourism and resistance tourism}

The Tucum initiatives, especially the analyzed ones (Icapuí, Beberibe, Ponta Grossa, and Prainha do Canto Verde), have a tourism potential for several segments aimed at local culture and environment preservation, based on a history of resistance concerning the land defense and community organization. The community tourism in Ceará had a significant boost through the II Sustainable Tourism International Seminar in May 2008, when the National Tourism Counsel started to recognize community tourism in Brazil. At the occasion, the Ministry of Tourism presented community tourism experiences over the country and compromised to support new initiatives (Coelho, Caetano \& Santos, $\underline{2016})$.

In the '90s, beaches of the region were threatened by devious and mass tourism, which has as consequences the land and biodiversity loss. From this perspective, the community, especially the Canto Verde residents, decided that they did not want this kind of tourism. Since it explores the place socially and environmentally, pointing to a series of impacts such as quality of life and quiet loss, and their stay in the community. From then on, they sought different tourism, one with more benefits than just money. So, in 1998 the Community Ecotourism Seminar in Prainha do Canto Verdem was held, being considered a landmark to the development of community ecotourism as a guarantee, statement, and defense of the land; as well as an income and sustainability alternative. Thus, the Prainha do Canto Verde became reference regarding the assignment and structuration of different tourism concerned with integration and conservation of ocean-coastal ecosystems and daily relationships. Canto Verde became an extractive reserve in 2009; this configures a conquest and strengthening of livelihoods and biodiversity preservation (Ribeiro, 2008).

Prainha do Canto Verde is considered a Conservation Unit (UC) for Sustainable Use. The goal is to protect the living manner and the local culture, besides assuring the sustainable use of natural resources, classified as a Marine Extractive Reserve (Resex), established by the Federal Decree of June 5, 2009 (Brasil, 2009) . The coastal line where the Resex is assembled has a total area of 29.804,99 hectares, involving the Costa Sol Nascente tourist destination, composed of Porto das Dunas (Aquiraz), Praia das Fontes, Morro Branco (Beberibe), and Canoa Quebrada (Aracati) beaches, all known for its great tourism potential. This area, since the '90s, suffers from the real estate speculation due to uncontrolled tourism activities, which is a characteristic of the mass tourism and the pressure to build summer houses (Costa, 2007; Coelho, Caetano \& Santos, 2016). Regarding the economic aspects, the main activity is the extractivism, and subsistence farming and small animal husbandry as supplementary income (ICMBIO, 2011).

Therefore, there is a straight relation with sustainable practices once there are algae species preservation projects and the very own CBT in Icapuí named itself "sustainable community tourism". The Ponta Grossa community also received a clean beach award, and it stands out for its environmental awareness, present in the residents' actions and speech. 


\section{Conclusion}

The methodological process of the present paper allowed exploratory and descriptive research with field observations. Through bibliographic research, we identify and codify the CBT initiatives, making it clear the recognition and development of tourism and the quality of life and awareness improvement. In this sense, we sought to identify the developed activities that support people's training, besides the performed activities such as lodging, eating, products sale, and others. Regarding the studied categories, the ecotourism is highlighted as a differential, besides CBT and land valuation, assisting the awareness and leadership training.

It is noteworthy that for three decades ago, many CBT projects have been promoted all over the world as a development synonym, and despite lots of these projects receive public funding, especially in indevelopment countries, there are no results of their qualitative analysis. In other words, the government does not evaluate the success or failure of these public funding initiatives. Therefore, the benefits to local communities that developed CBT projects remain widely disqualified (Kibicho, 2010; Teixeira, Vieira \& Mayr, 2019). Another item to emphasize in both projects is the need for partnership and articulation with several institutions to remain actives. In this sense, since the beginning, they seek these partnerships with both private and public institutions, in order to train the actors in several areas, such as Senar, Epagri, Terramar Institute, Caiçara Institute, and others.

About territory recognition, both Acolhida na Colônia and Rede Tucum acknowledge CBT as a viable alternative to local communities, attracting more visitors with environmental awareness and culture valuation. However, these initiatives are facing some difficulties over the last few years about the limited management ability of community tourism networks, the inexistence (or a significant reduction) of public policies for this kind of initiative, communication issues, and the strong influence of traditional tourism, based on market's logic. Besides that, there is also the lack of specific legislation for the development of community-based tourism, specifically the ones developed by family farmers and people supported by Law 11.326/2006 (Guzzatti, 2018).

However, in the Acolhida na Colônia, CBT reveals itself as a new opportunity for these farmers, through lodging, food, and leisure activities. In the countryside, tourism is now seen as a supplementary income for the families, keeping their authenticity, saving the cultural heritage, and improving their living conditions. Regarding the Rede Tucum, ecotourism is a matter of discussion and a differential in products and services, where more and more people seek experiences in places still preserved.

Despite the difficulties in CBT development, these initiatives have remained in the territory due to the strong articulation between the leaders, partnerships with educational institutions, and the maintenance of the methodology carried out by the project's technical team. In terms of future perspectives and challenges, it is promoting development-oriented policies that support productive activities, decent job creation, entrepreneurship, creativity, innovation, and encourage the formalization and growth of the business, including through financial help. In this sense, the CBT understands its function through better use of productive aspects and the strengthening of family farming, fishing, extractivism, among others, to contribute to the generation of income and improvement in the quality of life of traditional communities.

\section{Limitation and study forward}

The research had limitations related to the lack of infrastructure to reach some fishing communities and more in-depth research on TBC projects active in the Brazilian territory, as well as the existing challenges in the perspective of the community's Local Sustainable Territorial Development. The authors addressed in this study, point to the need for current development processes to start thinking about the place and people, which would only be possible through the strengthening of communities. Regarding the quality of the infrastructure and services to be offered, they become difficult questions to be measured or described throughout the research due to the limited time to conduct field collections (Guzzatti, 2018). Therefore, new studies can be elaborated addressing themes related to the adoption of a participatory methodology that allows the exchange of knowledge, the collective construction of knowledge, the establishment of principles and values

of the type of tourism that 
is intended to be developed and that stimulates cooperation for the success of a TBC project, in addition to public policies, whether Federal, State or Municipal to support the implementation of TBC projects in Brazil.

\section{Acknowledgement}

To the graduate program in Tourism and Hospitality at Univali and the Capes scholarship program.

\section{References}

AAAC - Associação Acolhida na Colônia (2020). Santa Rosa de Lima. Disponível em: < http://www.acolhida.com.br/>. Acesso em 18 de abril.

Brambatti, L. E.; Nitsche, L. B. (2018). Associativismo e participação comunitária: o roteiro rural Caminhos de Guajuvira, Araucária-PR, Brasil. Revista Rosa dos Ventos Turismo e Hospitalidade, 10 (1), 71-84.

Brasil. Ministério do Meio Ambiente. Decreto $n^{\circ} S / N$ (2009). Dispõe sobre a criação da reserva extrativista prainha do canto verde, no Município de Beberibe, no Estado do Ceará, e dá outras providências. Diário Oficial da União, Brasília-DF, seção 1.

Bursztyn, I. et al. (2009). Turismo para quem? Sobre caminhos de desenvolvimento e alternativas para o turismo no Brasil. In: BARTHOLO, R.; SANSOLO, D.G.; Bursztyn, I. Turismo de Base Comunitária diversidade de olhares e experiências brasileiras. (pp. 76 - 91). Rio de Janeiro: Editora Letra e imagem, parte I.

Brusadin, L. B.; Netto, A. P. (2016). La dádiva y el intercambio simbólico: supuestos sociológicos y filosóficos para la teoría de la hospitalidad en las sociedades antiguas y modernas. Estudios y Perspectivas en Turismo, 25, 520-538.

Cazzella, A. A. (2007). Base de serviços rurais estratégicos à promoção do desenvolvimento territorial no Brasil: uma análise prospectiva. XLV Congresso da sociedade Brasileira de economia, administração e sociologia rural - SOBER, Londrina- PR.

Coelho, S.; Caetano, A.; Santos, J. (2016). O turismo comunitário e sua contribuição ao desenvolvimento sustentável da prainha do Canto Verde, Beberibe - Ceará. Rev. Geogr. Acadêmica. 10 (2), 116-128.

Coriolano, L. N. M. T. (2009). Arranjos produtivos locais do turismo comunitário: atores e cenários em mudança. Fortaleza: EdUECE.

Coriolano, L. N.; Vasconcelos, F. P. (2012). Turismo, território e conflitos imobiliários. Fortaleza, EdUECE.

Costa, M. C. Fortaleza: expansão urbana e organização do espaço. In: Silava, J. (Org.). (2007). Ceará: um novo olhar geográfico. 2. ed. Fortaleza: Demócrito Rocha.

Damo, M. R. S. (2006). Análise da descentralização administrativa do governo do estado e os efeitos da fragmentação territorial no oeste catarinense. Florianópolis. Dissertação de mestrado em engenharia civil, Universidade Federal de Santa Catarina.

Deere, D. C. \& Royce, F. S. (2019). Provisioning Cuba's private restaurants: linking tourism and agriculture. Tourism Planning \& Development, 675-695.

Guzzatti, T. (2010). O agroturismo como elemento dinamizador na construção de territórios rurais: O caso da Associação de Agroturismo Acolhida na Colônia em Santa Rosa de Lima (SC). Florianópolis. Tese doutorado em geografia, Universidade Federal de Santa Catarina.

Guzzatti, T. (2018). Experiências criativas no turismo de base local. Encontro Nacional de Turismo com Base Local. Recife.

Gómez, C. R. P. et al. (2015). Turismo de base comunitária como inovação social: congruência entre os constructos. Pasos. Revista de Turismo y Patrimonio Cultural, 13 (5), 1213-1227.

Grimm, I. J., Sampaio, C. (2011). Turismo de base comunitária: convivencialidade e conservação ambiental. Revista Brasileira de Ciências Ambientais, p. 57-68.

Henche, B. G.; Carrera, E. S. (2017). Associacionismo, redes y marketing em la transformación hacia el turismo experiencial: el caso del barrio de las letras Madrid. Cuadernos de Turismo, (40), 315338.

Holladay, P. J. \& Powell, R. B. (2013). Resident perceptions of social-ecological resilience and the sustainability of community-based tourism development in the Commonwealth of Dominica. Journal of Sustainable Tourism, 16 (3), 1188-1211. 
ICMBIO (2011). Relatório do Grupo de Trabalho criado pela Portaria ICMBIO. n. 550/2010. DOU de 29/10/2010, referente à Reserva Extrativista Prainha do Canto Verde.

Irving, M. A. (2009). Reinventando a reflexão sobre turismo de base comunitária: inovar é possível? In: Bartholo, R.; Sansolo, D.G.; Bursztyn, I. Turismo de base comunitária diversidade de olhares e experiências Brasileiras. (pp.108-121). Rio de Janeiro: Editora Letra e Imagem.

Kibicho, W. (2010). Community-based Tourism: A Factor-Cluster Segmentation Approach. Journal of Sustainable Tourism, 16 (7), 211-231.

Lee, T. H. \& Jan, F.-H. (2019). Can community-based tourism contribute to sustainable development? Evidence from residents' perceptions of the sustainability. Tourism Management, 70, 368-380.

Machado, A. L.; Tomazzoni, E. L. (2011). A regionalização turística do Rio Grande do Sul e sua contribuição como referência para a gestão regionalizada do turismo no Brasil. Rev. Bras. Pesq. Tur. São Paulo. 5 (2), 226-247.

Maldonado, C. (2009). O turismo comunitário na América Latina: gênesis, características e políticas. Estudios y Perspectivas en Turismo, (25), p. 439 - 459. En: Bartholo, R.; Sansolo, D. \& Bursztyn, I. (Orgs.) Turismo de base comunitária: diversidade de olhares e experiências brasileiras. (pp. 25-44). Letra e Imagem, Rio de Janeiro.

Maldonado, C. (2006). Turismo y comunidades indígenas: Impactos, pautas para autoevaluación y códigos de conducta. SEED Documento de trabajo. n. 79. Programa de desarrollo de pequenas empresas. OIT, Ginebra.

Mayaka, M; Croy, W. G. \& Cox, J. W. (2017). Participation as motif in community-based tourism: a practice perspective. Journal of Sustainable Tourism, 16(8), 416-432.

Mano, A. D. (2017). Turismo de base comunitária na favela Santa Marta (RJ): oportunidades sociais, econômicas e culturais. Rev. Bras. Pesq. Tur. São Paulo, 11(3), 413-435.

Manzanares, A. F. A.; Mateos, H. M. S. (2017). El acesso a los destinos rurales: uma perspectiva para la planificación territorial del turismo em uma región de interior (Castilla-la Mancha). Cuadernos de Turismo, 251-272.

Miranda. A. A. B. R. Pol. (2012). O conceito de território e as recentes políticas de desenvolvimento rural e suas contradições no estado do Maranhão. Públ., São Luís, 16 (1), 123-132.

Moraes et al. (2017). Trilhando o turismo de base comunitária em Minas: um novo caminho das gerais. CULTUR, 11(1).

Moraleda, L. F.; Mazón, A. M.; Izquierdo, S. R. (2016). El turismo solidário como instrumento de desarrollo: um estúdio de caso para analizar las principales motivaciones de los turistas. Cuadernos de Turismo, 37, 227-242.

Okazaki, E. (2008). A community-based tourism model: its conception and use. Journal of Sustainable Tourism, 16(5), 511-529.

Onyx, J.; Edwars, M.; Bullen, P. (2017). The intersection of social capital and power: an application to rural communities. Rural Society, 17 (3), 215-230.

Palacios, C. G. (2016). Turismo comunitario en Ecuador: ¿ Quo Vadis?. Estudios y Perspectivas en Turismo, (25), $597-614$.

Pires, P. dos S. (2002). Dimensões do ecoturismo. São Paulo: Editora Senac.

Ribeiro, G. (2008). Turismo de Base Comunitária. Revista Global Tourism, 4 (2).

Rodrigues, B. A. (2006). Turismo e territorialidades plurais - lógicas excludentes ou solidariedade organizacional. Enpublicación: América Latina: cidade, campo e turismo. AmaliaInés Geraiges de Lemos, Mónica Arroyo, María Laura Silveira. CLACSO, Consejo Latino americano de Ciências Sociales, San Pablo. Diciembre.

Ruschmann, D. V. M. (1999). Turismo e planejamento sustentável: a proteção do meio ambiente. 5. ed. Campinas, SP: Papirus.

Sampaio, C. A. C.; Zamigman A, G. (2012). Estudo da demanda turística: experiência de turismo comunitário da Microbacia do rio sagrado, Morretes (PR). CULTUR, 6 (1), 25-39.

Santos, M. (2004). A natureza do espaço. 4. ed. São Paulo: EDUSP.

Sharpley, R. (2014). Host perceptions of tourism: A review of the research. Tourism Management, 42, 37-49.

Silva, Y. F.; Borborema, F. B.; Christoffoli, A. (2016). Turismo comunitário e desenvolvimento local: uma revisão integrativa sobre a acolhida na colônia. Caderno Virtual de Turismo, 19(2). 
Teixeira, F. R.; Vieira, F. D.; Mayr, L. R. (2019). Turismo de base comunitária: Uma abordagem na perspectiva da análise de clusters. Turismo: Visão e Ação, 21 (2), 2-21.

Tolkach, D., King, B., \& Pearlman, M. (2013). An attribute-based approach to classifying communit based tourism networks. Tourism Planning \& Development, 10 (3), 319-337.

Vera, M. P. (2016). El Turismo comunitário como uma estratégia de supervivência: Resistencia y reivindicación cultural indígena de comunidades mapuche en la Región de los Ríos (Chile). Estudios y Perspectivas en Turism, (25), 439 - 459. 